\title{
Bixin and fucoxanthin sensitize human lung cancer and cervical cancer cell to cisplatin in vitro
}

Agustina Dwi Retno Nurcahyanti ${ }^{{ }^{*}}$ D, Lia Kusmita ${ }^{2}$ and Michael Wink ${ }^{3}$

\begin{abstract}
Objective: Cisplatin is a conventional anticancer drug that generates reactive oxygen species and causes apoptosis. However, many cancer cells develop alterations in the ATP binding cassette transporter responsible for the uptake and efflux process, which leads to resistance. Many natural products have shown potential to compete with ATP binding cassette transporter and may sensitize resistant cells to cisplatin. Studies have shown pro-oxidant effect of carotenoids that promote apoptosis of cancer cells. Bixin and fucoxanthin are well-known carotenoids with known antioxidant properties, however their bioactivity in lung cancer cells, clinically known to develop resistance due to ATP binding cassette transporter, has been minimally studied. This study is the first to investigate the potential of bixin and fucoxanthin to sensitize human lung cancer cell line, A549 and cervical cancer cell line, HeLa, to cisplatin. Drug combination method developed by Chou and Talalay theorem was employed.
\end{abstract}

Result: Employing the best combination ratio, this study shows selective sensitization of cancer cells to cisplatin after bixin and fucoxanthin treatment. Further study on the mechanism of action in specific types of cancer cells is warranted. It may improve cisplatin sensitivity in tumors and rational use of cancer drugs.

Keywords: Cisplatin, Bixin, Fucoxanthin, Lung cancer, Drug combination, ABC transporter, Pro-oxidant

\footnotetext{
*Correspondence: adr.nurcahyanti@atmajaya.ac.id

1 Department of Pharmacy, School of Medicine and Health Sciences,

Atma Jaya Catholic University of Indonesia, Pluit Raya 2, Jakarta 14440,

Indonesia

Full list of author information is available at the end of the article
}

(c) The Author(s) 2021. Open Access This article is licensed under a Creative Commons Attribution 4.0 International License, which permits use, sharing, adaptation, distribution and reproduction in any medium or format, as long as you give appropriate credit to the original author(s) and the source, provide a link to the Creative Commons licence, and indicate if changes were made. The images or other third party material in this article are included in the article's Creative Commons licence, unless indicated otherwise in a credit line to the material. If material is not included in the article's Creative Commons licence and your intended use is not permitted by statutory regulation or exceeds the permitted use, you will need to obtain permission directly from the copyright holder. To view a copy of this licence, visit http://creativecommons.org/licenses/by/4.0/. The Creative Commons Public Domain Dedication waiver (http://creativeco mmons.org/publicdomain/zero/1.0/) applies to the data made available in this article, unless otherwise stated in a credit line to the data. 


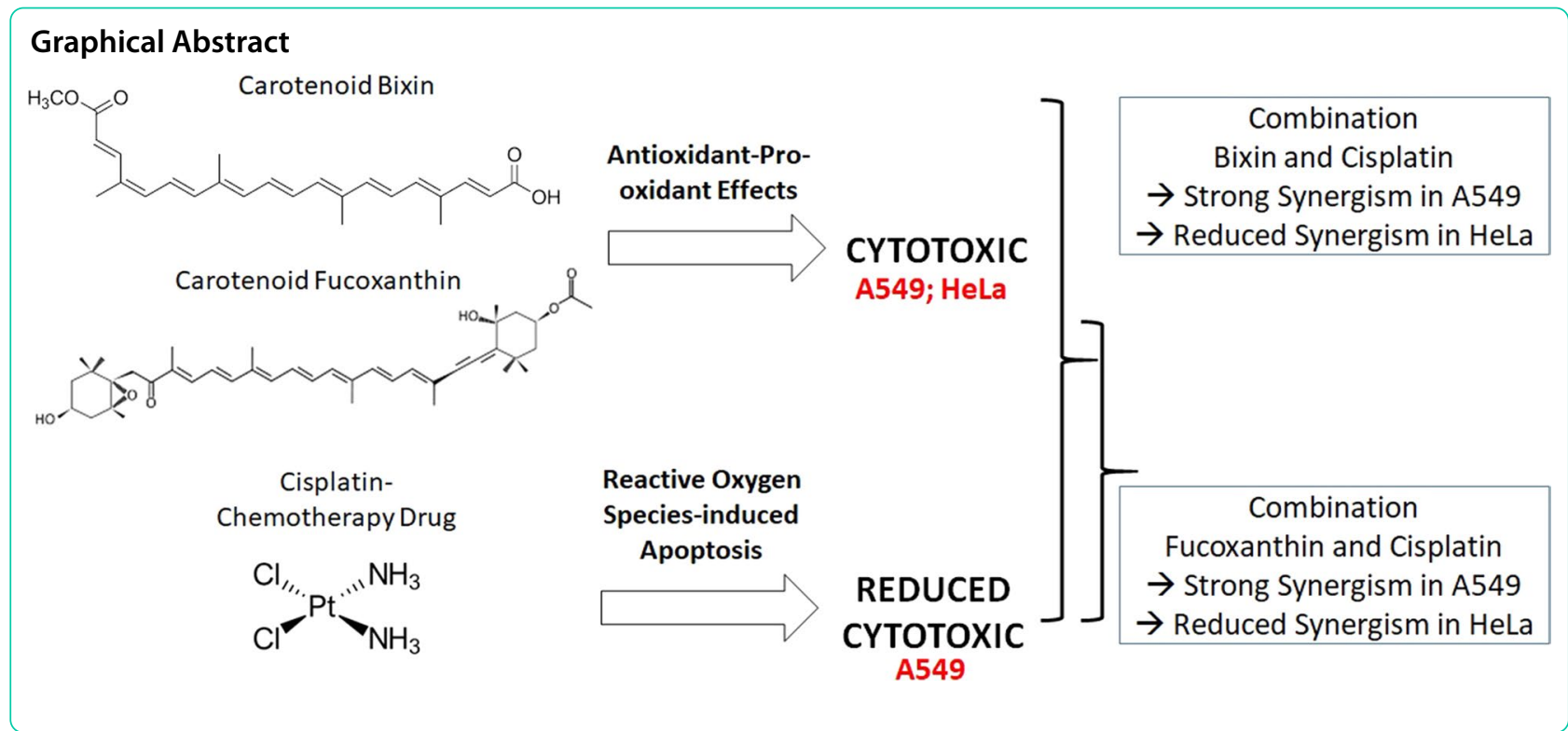

\section{Introduction}

Cancer is a genetic disease and currently the leading cause of death worldwide with the most common cases being lung, colon and rectum, liver, stomach, and breast $[1,2]$. Although many therapeutic approaches have been developed, the number of deaths keeps increasing [2]. Extensive heterogeneity within patients' cancer cell has important implications on the type of treatment provided [1, 3]. Many tumors develop tolerance or resistance against cytotoxic drugs used in cancer chemotherapy. One such mechanism is by overexpression of the ATP binding cassette $(A B C)$ to modulate efflux of various drugs out of the cells, thereby reducing intracellular drug concentration to below effective level [4].

Cisplatin is one of many well-known chemotherapeutic drugs that has been widely used to treat cancer such as testicular, bladder, ovarian, head and neck, as well as lung cancer [5]. It inhibits the ability of purine base crosslinking at the nucleic acid, inhibits DNA repair mechanisms, leading to DNA damage, and induces cell apoptosis [5]. However, cisplatin resistance has been reported in different cancer cells. Changes in membrane lipid composition and the mechanism of drug efflux are example of adaptations that results resistance, hence negatively affecting clinical outcome [6-10]. As tumor cells can acquire resistance by modulating several pathways, combining between two or more different drugs modalities can prevent development of resistance [11]. Evidence of drug resistance and toxicity of cisplatin has also led to the consideration of combining it with other drugs/agents $[5,12]$, for example those that modulate drug efflux [13].
Natural products, like carotenoids, have shown the capacity to enhance response of cytotoxic drug to cancer cells $[14,15]$. Diverse functional groups and isomer configuration on the hydrocarbon backbone of carotenoids affects their bioactivity [16]. Activity of carotenoids in biological systems is dependent on its concentration and in turn also affects the presence of other oxidants and radicals, as observed in MCF-7 breast cancer cells [17] and human leukemia HL-60 cells [18]. In addition, the activity also depends on the molecular characteristic of cancer cells, for instance estrogen receptor (ER) negative MDA-MB-231 human breast cancer cells are more susceptible to lycopene treatments than the ER-positive MCF-7 cells [19]. Understanding carotenoid's nature, antioxidant or pro-oxidant, in specific types of cells and tissue, is important.

Bixin and fucoxanthin are well-known antioxidant that also exhibits pro-oxidant activity. A study on mouse hepatic BNL CL.2 cells has shown an increased cellular production of reactive oxygen species (ROS) after incubation with fucoxanthin, indicating pro-oxidant nature of fucoxanthin [20]. The effect of fucoxanthin in ROS-mediated apoptosis then confirmed in human promyelocytic leukemia cells [21] and human glioma cells [22]. When combined with other drugs, fucoxanthin has shown the capacity to sensitize multidrug resistant cancer cells to doxorubicin by inducing apoptosis and inhibiting metabolic enzymes responsible for resistance [23]. Recent study on bixin has shown the capacity of this apocarotenoid to sensitize human melanoma cells to decarbazine via ROS-mediated cytotoxicity [24].

No study was found combining bixin and fucoxanthin with cisplatin in clinically resistant cancer cells, like lung 
cancer. We hypothesized that both carotenoids can sensitize lung and cervical cancer cells to cisplatin when used in the correct concentration, in which the pro-oxidant and antioxidant nature of carotenoids are sufficient and balanced to induce apoptosis. An exact dose ratio of combination may potentially exhibit enhanced therapeutic outcomes, reduce toxicity, and prevent drug resistance on a specific type of cancer cell.

\section{Main text \\ Methods \\ Chemical and cell lines}

The following cancer cell lines obtained from American Type Culture Collection (ATCC) were used in current study: human lung cancer cell line, A549 and human cervical cancer cell line, HeLa. Cancer cell culture media, supplements, and antibiotics were purchased from PANBiotech, Aidenbach, Germany. Trypsin, trypan blue $0.4 \%$ solution, and 10X Phosphate Buffered Saline (PBS) were purchased from Sisco Research Laboratories Pvt. Ltd. (SRL), Mumbai, India. MTT (3-(4,5-Dimethylthiazol2-yl)-2,5-Diphenyltetrazolium Bromide) was obtained from Assay Genie, Dublin, Ireland. Cisplatin, Bixin, and Fucoxanthin were purchased from Sigma-Aldrich, Missouri, United State. All laboratory plastic ware were obtained from Wuxi NEST Biotechnology Co., Ltd, Jiangsu, China.

\section{Culture of cancer cells}

HeLa cells was maintained in Dulbelcco's modified Eagle's medium (DMEM) with Glutamax, supplemented with $10 \%$ foetal bovine serum (FBS), $500 \mathrm{U} / \mathrm{ml}$ penicillin and $500 \mu \mathrm{g} / \mathrm{ml}$ streptomycin, and $1 \%$ non-essential amino acids (NEAA). A549 cells were maintained in culture media mentioned above, without NEAA. All cells were cultivated at $37^{\circ} \mathrm{C}$ and $5 \% \mathrm{CO}_{2}$.

\section{Cytotoxicity assay}

Cytotoxicity assay was used to determine the Inhibitory Concentration (IC) or Effective Dose (ED) of each substance required to inhibit cell growth at three different levels, namely $\mathrm{IC}_{25}, \mathrm{IC}_{50}$, and $\mathrm{IC}_{75}$. Dose-dependent cytotoxicity was examined using the 3-(4,5-dimethylthiazol-2-yl)-2,5-diphenyltetrazolium Bromide (MTT) assay. Cells $\left(5 \times 10^{4}\right)$ were seeded into each well of the 96-well plates and incubated for $24 \mathrm{~h}$, after which cisplatin, bixin, and fucoxanthin were added into the media and cells were incubated for an additional $48 \mathrm{~h}$. Postincubation with test compounds, $100 \mu \mathrm{L}$ of $0.5 \mathrm{mg} / \mathrm{ml}$ MTT was added to each well and incubated for $3 \mathrm{~h}$ to allow viable cells to produce formazan crystals. Crystals formed were then dissolved in $100 \mu \mathrm{L}$ development solution and incubated for $30 \mathrm{~min}$ in a shaker, the absorption of the formazan was measured at $570 \mathrm{~nm}$ using Nanoquant Infinite M200 Pro (Tecan, Switzerland). Cell viability was also confirmed using trypan blue dye solution.

\section{Combination design}

Principle of cancer drug development is growth inhibition or killing of cancer cell, without having a toxic or adverse effect on non-cancer cells, ensuring clinical efficacy and safety. This principle is applicable when developing combinatorial therapy to overcome drug resistance and preventing development of inoperable solid tumors. For successful combination, individual therapeutic component must achieve minimum effective dose (MED) producing selective lethality while maintaining a balance between clinical efficacy and safety [11]. Only a few phase 2 trials examine MED. Most drug approvals are assessed based on the use of maximum tolerated dose (MTD), the highest dose that can be administrated without significant adverse consequences [11]. In current in vitro study, inhibition concentration of individual agent (carotenoids or cisplatin) that inhibit $50 \%$ of cancer cell growth $\left(\mathrm{IC}_{50}\right)$ was employed. $\mathrm{IC}_{50}$ is the MTD equivalent of chemotherapeutic drug to achieve therapeutic outcome. In addition, as cisplatin is well known cytotoxic agent demonstrated organs toxicity [5], the second combination tested had cisplatin concentration lowered to $\mathrm{IC}_{25}$ to mimic the MED, whereas concentration of carotenoids was increased to $\mathrm{IC}_{75}$ to mimic the MTD of the less cytotoxic agent. This was done to achieve efficacy and safety of the combinatorial outcome. In addition, many studies explain that pleiotropic agent, including natural product like carotenoids, can induce biochemical reaction even when administered at below efficacious dose [11]. In current study lower concentration of carotenoids, $\mathrm{IC}_{25}$, combined with $\mathrm{IC}_{50}$ of cisplatin was also performed to determine the effect of combination even using lower concentration of carotenoids.

A combination design was performed using constant ratios of tested substances based on method developed by Chou [25]. Three constant ratio of combinations (Carotenoid:Cisplatin, $\mathrm{IC}_{25}$ : $\mathrm{IC}_{50}$ (Combo 1), $\mathrm{IC}_{50}$ : $\mathrm{IC}_{50}$ (Combo 2), and $\mathrm{IC}_{75}: \mathrm{IC}_{25}$ (Combo 3)), were tested in human lung and cervical cancer cells. The ratio of the drug combinations was applied to the 96 well-plates with two folds' dilution in each well. The cytotoxic activity of combination was performed using MTT assay as outlined above.

Drug interactions were assessed using the combination index method (CI), based on the median-effect principle to calculate $D_{x}$, the dose of a drug that inhibits ' $x$ ' percent of cells [25]: 
Table 1 Combination index and drug interaction in A549 cell line

\begin{tabular}{|c|c|c|c|}
\hline Combination & $\begin{array}{l}\mathrm{IC}_{50} \text { of drug in combination } \\
\text { (Mean } \pm \mathrm{SD} \text { ) }\end{array}$ & $\begin{array}{l}\text { Combination index at ED } \\
(\text { Mean } \pm \text { SD) }\end{array}$ & Drug interaction \\
\hline \multirow[t]{4}{*}{ Fucoxanthin and cisplatin Combo 1} & $21.961 \pm 1.929$ & $\mathrm{ED}_{50}: 0.178 \pm 0.032$ & Strong synergism \\
\hline & & $\mathrm{ED}_{75}: 0.084 \pm 0.020$ & Very strong synergism \\
\hline & & $\mathrm{ED}_{90}: 0.043 \pm 0.021$ & Very strong synergism \\
\hline & & $\mathrm{ED}_{95}: 0.029 \pm 0.020$ & Very strong synergism \\
\hline \multirow[t]{4}{*}{ Fucoxanthin and cisplatin Combo 2} & $19.382 \pm 2.987$ & $\mathrm{ED}_{50}: 0.186 \pm 0.032$ & Strong synergism \\
\hline & & $E D_{75}: 0.082 \pm 0.005$ & Very strong synergism \\
\hline & & $\mathrm{ED}_{90}: 0.038 \pm 0.004$ & Very strong synergism \\
\hline & & $E D_{95}: 0.023 \pm 0.004$ & Very strong synergism \\
\hline \multirow[t]{4}{*}{ Fucoxanthin and cisplatin Combo 3} & $5.478 \pm 0.532$ & $\mathrm{ED}_{50}: 0.188 \pm 0.042$ & Strong synergism \\
\hline & & $\mathrm{ED}_{75}: 0.097 \pm 0.019$ & Very strong synergism \\
\hline & & $\mathrm{ED}_{90}: 0.050 \pm 0.011$ & Very strong synergism \\
\hline & & $\mathrm{ED}_{95}: 0.033 \pm 0.008$ & Very strong synergism \\
\hline \multirow[t]{4}{*}{ Bixin and cisplatin Combo 1} & $25.219 \pm 1.070$ & $\mathrm{ED}_{50}: 0.165 \pm 0.023$ & Strong synergism \\
\hline & & $E D_{75}: 0.077 \pm 0.019$ & Very strong synergism \\
\hline & & $\mathrm{ED}_{90}: 0.038 \pm 0.014$ & Very strong synergism \\
\hline & & $E D_{95}: 0.024 \pm 0.011$ & Very strong synergism \\
\hline \multirow[t]{4}{*}{ Bixin and cisplatin Combo 2} & $30.316 \pm 1.859$ & $\mathrm{ED}_{50}: 0.196 \pm 0.039$ & Strong synergism \\
\hline & & $E D_{75}: 0.094 \pm 0.022$ & Very strong synergism \\
\hline & & $\mathrm{ED}_{90}: 0.047 \pm 0.014$ & Very strong synergism \\
\hline & & $\mathrm{ED}_{95}: 0.030 \pm 0.010$ & Very strong synergism \\
\hline \multirow[t]{4}{*}{ Bixin and cisplatin Combo 3} & $21.330 \pm 1.153$ & $\mathrm{ED}_{50}: 0.132 \pm 0.037$ & Strong synergism \\
\hline & & $\mathrm{ED}_{75}: 0.074 \pm 0.025$ & Very strong synergism \\
\hline & & $\mathrm{ED}_{90}: 0.029 \pm 0.013$ & Very strong synergism \\
\hline & & $\mathrm{ED}_{95}: 0.033 \pm 0.008$ & Very strong synergism \\
\hline
\end{tabular}

$$
C I=\frac{(D)_{1}}{\left(D_{x}\right)_{1}}+\frac{(D)_{2}}{\left(D_{x}\right)_{2}}
$$

CompuSyn Ver.1.0 developed by Ting-Chao Chou and Nick Martin was used to interpretate the combination effect and calculate combination index (CI) as mentioned in our previous study [26-28]. Cell viability was confirmed using trypan blue dye solution.

\section{Dose Reduction Index}

Dose Reduction Index (DRI) was defined as the reduction of dose required when used in combination to give the same level of inhibition in single drug treatment. DRI was analyzed using CompuSyn Ver.1.0 developed by Ting-Chao Chou and Nick Martin:

$$
D R I=\frac{(D x)_{1}}{(D)_{1}}
$$

\section{Cell viability assay}

The viability of treated cells was examined using trypan blue dye solution according to the standard method.
Cell suspension $(100 \mu \mathrm{L})$ was mixed with equal volume of the dye and examined under an inverted microscope within $5 \mathrm{~min}$. Cells with a translucent cytoplasm were regarded as viable cells while those that appeared blue were regarded as non-viable.

\section{Statistical analysis}

All data are indicated as a mean \pm standard deviation. The dose-response curves using CompuSyn Ver.1.0 developed by Ting-Chao Chou and Nick Martin was employed to calculate Effective Dose (ED) and Combination index at $\mathrm{ED}_{50}, \mathrm{ED}_{75}, \mathrm{ED}_{90}$, and $\mathrm{ED}_{95}$ values.

\section{Results and discussion}

Study of bixin and fucoxanthin, pro-oxidant and antioxidant carotenoids, in combination with cisplatin, a ROSbased anticancer drug is very limited. Current study used lung cancer cell line, A549, to understand the effect of bixin and fucoxanthin on the synergistic interaction and dose reduction index of cisplatin.

Treatment using individual agent showed that A549 cells demonstrates reduced sensitivity to 
Table 2 Combination index and drug interaction in HeLa cell line

\begin{tabular}{|c|c|c|c|}
\hline Combination & $\begin{array}{l}\mathrm{IC}_{50} \text { of drug in combination } \\
\text { (Mean } \pm \text { SD) }\end{array}$ & $\begin{array}{l}\text { Combination index at ED } \\
(\text { Mean } \pm \text { SD) }\end{array}$ & Drug interaction \\
\hline \multirow[t]{4}{*}{ Fucoxanthin and cisplatin Combo 1} & $20.216 \pm 1.577$ & $\mathrm{ED}_{50}: 6.810 \pm 0.984$ & Strong antagonism \\
\hline & & $\mathrm{ED}_{75}: 2.497 \pm 0.683$ & Antagonism \\
\hline & & $\mathrm{ED}_{90}: 0.999 \pm 0.406$ & Nearly additive \\
\hline & & $\mathrm{ED}_{95}: 0.569 \pm 0.285$ & Synergism \\
\hline \multirow[t]{4}{*}{ Fucoxanthin and cisplatin Combo 2} & $8.698 \pm 0.526$ & $\mathrm{ED}_{50}: 2.961 \pm 0.865$ & Strong antagonism \\
\hline & & $\mathrm{ED}_{75}: 1.027 \pm 0.453$ & Nearly additive \\
\hline & & $\mathrm{ED}_{90}: 0.400 \pm 0.247$ & Synergism \\
\hline & & $\mathrm{ED}_{95}: 0.226 \pm 0.168$ & Strong synergism \\
\hline \multirow[t]{4}{*}{ Fucoxanthin and cisplatin Combo 3} & $2.583 \pm 0.425$ & $\mathrm{ED}_{50}: 0.694 \pm 0.188$ & Synergism \\
\hline & & $\mathrm{ED}_{75}: 0.410 \pm 0.133$ & Synergism \\
\hline & & $\mathrm{ED}_{90}: 0.244 \pm 0.092$ & Strong synergism \\
\hline & & $\mathrm{ED}_{95}: 0.171 \pm 0.071$ & Strong synergism \\
\hline \multirow[t]{4}{*}{ Bixin and cisplatin Combo 1} & $37.564 \pm 2.810$ & $\mathrm{ED}_{50}: 7.802 \pm 0.971$ & Strong antagonism \\
\hline & & $\mathrm{ED}_{75}: 2.884 \pm 0.546$ & Antagonism \\
\hline & & $\mathrm{ED}_{90}: 1.115 \pm 0.272$ & Slight antagonism \\
\hline & & $\mathrm{ED}_{95}: 0.602 \pm 0.167$ & Synergism \\
\hline \multirow[t]{4}{*}{ Bixin and cisplatin Combo 2} & $32.110 \pm 4.154$ & $\mathrm{ED}_{50}: 4.196 \pm 1.007$ & Strong antagonism \\
\hline & & $\mathrm{ED}_{75}: 2.229 \pm 0.582$ & Antagonism \\
\hline & & $\mathrm{ED}_{90}: 1.267 \pm 0.420$ & Moderate antagonism \\
\hline & & $\mathrm{ED}_{95}: 0.897 \pm 0.370$ & Slight synergism \\
\hline \multirow[t]{4}{*}{ Bixin and cisplatin Combo 3} & $31.303 \pm 0.673$ & $\mathrm{ED}_{50}: 2.250 \pm 0.547$ & Antagonism \\
\hline & & $\mathrm{ED}_{75}: 1.931 \pm 0.133$ & Antagonism \\
\hline & & $\mathrm{ED}_{90}: 1.744 \pm 0.442$ & Antagonism \\
\hline & & $\mathrm{ED}_{95}: 1.712 \pm 0.704$ & Antagonism \\
\hline
\end{tabular}

cisplatin $\left(\mathrm{IC}_{50} 149.997 \pm 18.789 \mu \mathrm{M}\right)$ when compared to fucoxanthin $\left(\mathrm{IC}_{50} 17.877 \pm 3.091 \mu \mathrm{M}\right)$ and bixin $\left(\mathrm{IC}_{50}\right.$ $15.029 \pm 3.693 \mu \mathrm{M}$ ) (Additional file 1: Table S1). The reduced response of A549 can be due to the mechanism of resistance. Several clinical and pre-clinical studies support the evidence that protein transporters play a vital contribution to the multidrug resistance of cancer cells [4], including ABCC1 that was identified in 1992 in human small-cell lung cancer cell lines [29]. The challenge in identifying whether drug transporter is the crucial target for reversal multidrug resistance is indeed important. The overexpression of multidrug resistance protein 1 (MDR-1) remains to become the significant marker in poor prognosis indicator for aggressive tumor phenotype. It indicates drug transporter plays a leading role before many intracellular metabolisms affecting multidrug resistance can be further elucidated [30].

Tables 1 and 2 illustrate the combination index between cisplatin and carotenoids (bixin or fucoxanthin) and the interpretation of drug interaction in A549 and HeLa cells, respectively, at four Effective Dose $\left(\mathrm{ED}_{50}, \mathrm{ED}_{75}, \mathrm{ED}_{90}\right.$, and $\left.E D_{95}\right)$. The interaction between carotenoid and cisplatin exhibits a synergistic fashion in A549 cells (Table 1), whereas different degrees of synergism was observed in HeLa cells (Table 2). The sensitivity of lung cancer A549 to cisplatin, as observed in this study, may be attributed to the inhibitory effect of fucoxanthin on the expression of transporter protein, thus increasing intracellular cisplatin concentration, exerting synergistic interaction, and finally leading to cell death (Table 1, Fig. 1).

This study is also the first to report bixin's ability to modulate cytotoxic effect of cisplatin on lung cancer and cervical cancer cell lines and reduce the required cisplatin dose to inhibit cell growth. One of the mechanisms underlying this finding is probably via inhibition of proteins responsible for multidrug resistance, as reported in previous studies using fucoxanthin, canthaxanthin, and $\beta$-carotene $[15,31]$.

Cisplatin works by generating reactive oxygen species (ROS) (8). Blocking antioxidant mechanism in cancer cells by cisplatin-induced ROS decreases their ability to balance oxidative homeostasis, damaging cellular compartments and leads to apoptosis. Carotenoids fucoxanthin is a molecule that can modulate the intracellular 

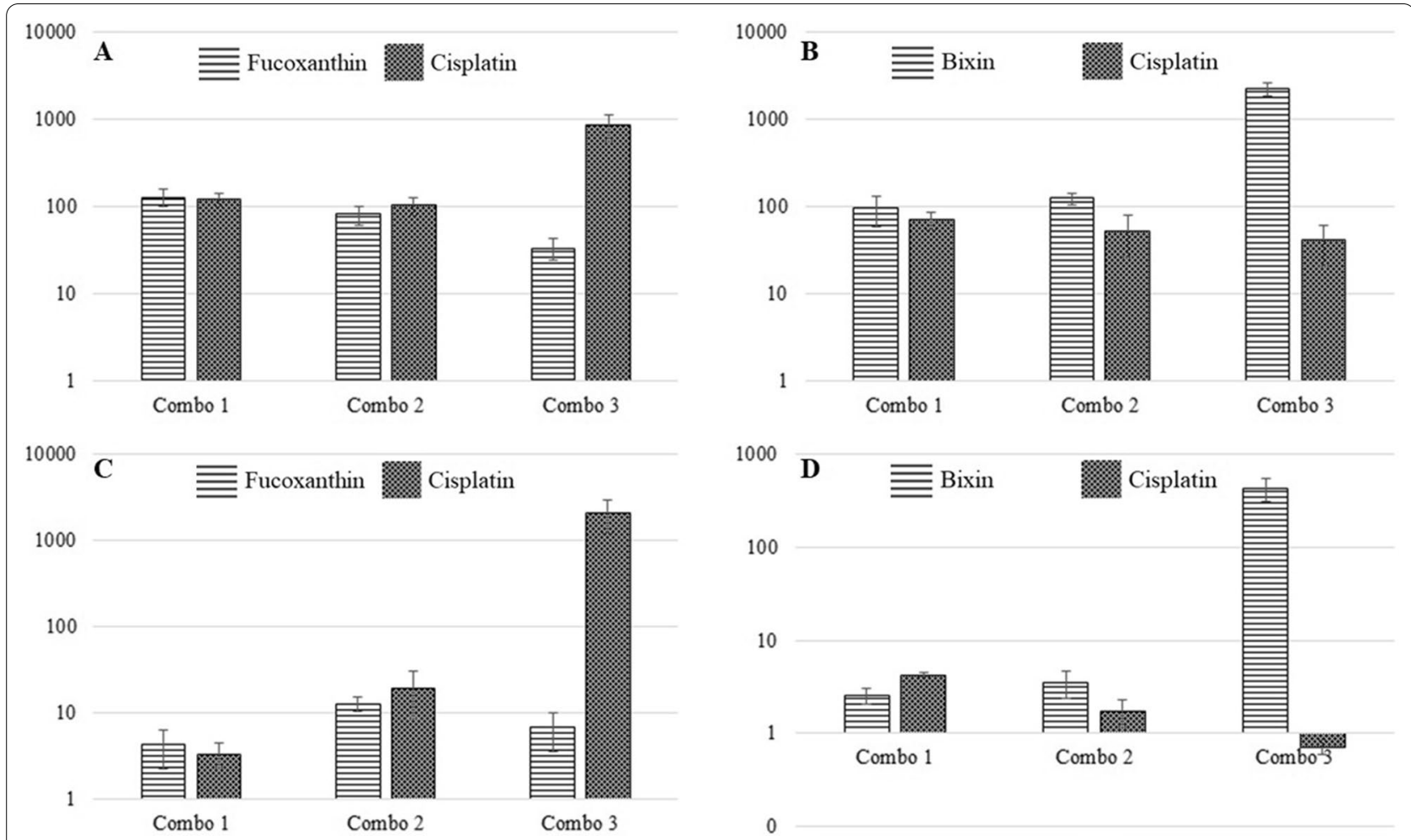

Fig. 1 Dose Reduction Index (DRI) of cisplatin and fucoxanthin or bixin at Effective Dose 95 (ED 95) in A549 cell lines (A, B) and HeLa cell line (C, D) at combination ratio carotenoid:cisplatin, $I C_{25}: I C_{50}$ (Combo 1), IC $C_{50}: I C_{50}$ (Combo 2), and IC $C_{75}: I C_{25}$ (Combo 3)

redox status, exerting both antioxidant and pro-oxidant properties, depending on concentration, cell type, and microenvironment of the cells [32]. The mechanism underlying the unfavorable interaction between carotenoids and cisplatin in HeLa cells could be due to the redox status (Table 2). The antioxidant property of bixin may reduce the accumulation of ROS generated by cisplatin in HeLa cells and, therefore, reduce its efficacy and decreased synergistic interaction [33].

The Dose Reduction Index is an estimated value employing simple mathematic calculation to see a reduced concentration of cytotoxic drugs in combination (Fig. 1). Potential interaction can be solely interpolated using combination index $(\mathrm{CI})$, based on the median-effect principle [25]. Use of low dose of cisplatin-based treatment, as seen in A549 cells (Table 1) and HeLa cells (Table 2), augments the sensitivity of cells and yields synergistic interaction with fucoxanthin. The higher dose of fucoxanthin $\left(\mathrm{IC}_{75}\right)$ used in the combination results in a higher dose reduction of cisplatin as observed in A549 and HeLa cell lines. On the other hand, the higher dose of bixin $\left(\mathrm{IC}_{75}\right)$ results no significant reduction of cisplatin dose, especially in HeLa cell (Fig. 1). In HeLa cell line, fucoxanthin and bixin may have potency as a cisplatin transporter inhibitor only at a balanced concentration. The activity was later hampered by the ability of carotenoids to act as an antioxidant and protect cancer cells from ROS-induced apoptosis. In comparison, the use of both carotenoids in the A549 cell line is promising as a drug transporter inhibitor without interfering with their antioxidant capacity that can inhibit ROS-induced cell death. The combination between carotenoid, an antioxidant compound, and ROS-inducing chemotherapeutic drugs in exact concentration exerts selective synergistic interaction. Upon targeting transporter, understanding diverse intracellular metabolic process can be further investigated and can potentially lead to the discovery of novel cancer therapeutics.

\section{Limitation}

Additional data should have been performed on the mRNA expression and protein activation of $A B C$ transporters. In addition, in-depth investigation on the mechanism of carotenoids pro-oxidant in various cancer cell types requires further investigation.

\section{Abbreviations}

ABC transporter: ATP-Binding Cassette Transporter; ABCC1: ATP Binding Cassette Subfamily C Member 1; Combo: Combination; Cl: Combination index; 
DMEM: Dulbelcco's modified Eagle's medium; DRI: Dose Reduction Index; ED: Effective Dose; FBS: Foetal bovine serum; IC: Inhibitory Concentration; MDR-1: Multi-Drug Resistance 1 gene; MED: Minimum effective dose; MTD: Maximum tolerated dose; MTT: 3-(4,5-Dimethyl-2-thiazolyl)-2,5-diphenyl-2H-tetrazolium bromide; NEAA: Non-essential amino acids; ROS: Reactive oxygen species.

\section{Supplementary Information}

The online version contains supplementary material available at https://doi. org/10.1186/s13104-021-05866-4.

Additional file 1: Table S1. Cytotoxicity of tested substances in cancer cell lines.

\section{Acknowledgements}

The authors thank Yogiara, Ph.D., for the permission to perform cell culture in his managed Laboratory.

\section{Authors' contributions}

ADRN conceptualized the project, conducted the experiments, analyzed the data, and wrote the manuscript, LK conducted the experiments and analyzed the data, and MW conceptualized the project, reviewed and edited the manuscript. All authors read and approved the final manuscript.

\section{Funding}

This research was funded by the Ministry of Research, Technology, and Higher Education, Indonesia under Research Grant No. 1208/LL3/PG/2021.

\section{Availability of data and materials}

The corresponding authors can provide relevant data from the study.

\section{Declarations}

Ethics approval and consent to participate

Not applicable.

\section{Consent for publication}

Not applicable.

\section{Competing interests}

The authors declare that they have no competing interests.

\section{Author details}

${ }^{1}$ Department of Pharmacy, School of Medicine and Health Sciences, Atma Jaya Catholic University of Indonesia, Pluit Raya 2, Jakarta 14440, Indonesia. ${ }^{2}$ Department of Pharmacy, STIFAR Yayasan Pharmasi Semarang, Letjend Sarwo Edhie Wibowo KM 1, Plamongansari Pucanggading, Semarang, Indonesia. ${ }^{3}$ Institute of Pharmacy and Molecular Biotechnology, Heidelberg University, Im Neuenheimer Feld 364, 69120 Heidelberg, Germany.

Received: 12 September 2021 Accepted: 29 November 2021 Published online: 18 December 2021

\section{References}

1. Loeb LA, Loeb KR, Anderson JP. Multiple mutations and cancer. Proc Natl Acad Sci USA. 2003;100:776. https://doi.org/10.1073/PNAS.0334858100.

2. World Health Organization. Cancer. 2021. https://www.who.int/newsroom/fact-sheets/detail/cancer.

3. Hanahan D, Weinberg RA. Hallmarks of cancer: the next generation. Cell. 2011;144:646-74.

4. Xiao H, Zheng Y, Ma L, Tian L, Sun Q. Clinically-relevant ABC transporter for anti-cancer drug resistance. Front Pharmacol. 2021;12:705.

5. Dasari S, Tchounwou PB. Cisplatin in cancer therapy: molecular mechanisms of action. Eur J Pharmacol. 2014;740:364. https://doi.org/10.1016/J. EJPHAR.2014.07.025.
6. Hall MD, Okabe M, Shen D-W, Liang X-J, Gottesman MM. The role of cellular accumulation in determining sensitivity to platinum-based chemotherapy. Annu Rev Pharmacol Toxicol. 2008;48:495-535. https:// doi.org/10.1146/ANNUREV.PHARMTOX.48.080907.180426.

7. Guang Y, Wang X-J, Huang L-J, Zhou YA, Tian F, Zhao J-B, et al. High ABCG4 expression is associated with poor prognosis in non-small-cell lung cancer patients treated with cisplatin-based chemotherapy. PLoS ONE. 2015;10:e0135576. https://doi.org/10.1371/JOURNAL.PONE.0135576.

8. Liang $X$, Huang $Y$. Physical state changes of membrane lipids in human lung adenocarcinoma A549 cells and their resistance to cisplatin. Int J Biochem Cell Biol. 2002;34:1248-55.

9. Zisowsky J, Koegel S, Leyers S, Devarakonda K, Kassack MU, Osmak M, et al. Relevance of drug uptake and efflux for cisplatin sensitivity of tumor cells. Biochem Pharmacol. 2007;73:298-307. https://doi.org/10.1016/J. BCP.2006.10.003.

10. Chen Y, Zhou H, Yang S, Su D. Increased ABCC2 expression predicts cisplatin resistance in non-small cell lung cancer. Cell Biochem Funct. 2021;39:277-86. https://doi.org/10.1002/CBF.3577.

11. Bridges AJ, Mehta RK, Shukla S, Schipper MJ, Lawrence TS, Nyati MK. Drug-development, dose-selection, rational combinations from bench-to-bedside: are there any lessons worth revisiting? Oncotarget. 2021;12:1032. https://doi.org/10.18632/ONCOTARGET.27931.

12. Tchounwou PB, Dasari S, Noubissi FK, Ray P, Kumar S. Advances in our understanding of the molecular mechanisms of action of cisplatin in cancer therapy. J Exp Pharmacol. 2021;13:303-28. https://doi.org/10. 2147/JEP.S267383.

13. Stefan SM. Multi-target ABC transporter modulators: what next and where to go? Future Med Chem. 2019;11:2353-8. https://doi.org/10. 4155/FMC-2019-0185.

14. Zhang Y, Li H, Zhang J, Zhao C, Lu S, Qiao J, et al. The combinatory effects of natural products and chemotherapy drugs and their mechanisms in breast cancer treatment. Phytochem Rev. 2019;19:1179-97. https://doi. org/10.1007/S11101-019-09628-W.

15. Eid SY, El-Readi MZ, Wink M. Carotenoids reverse multidrug resistance in cancer cells by interfering with $\mathrm{ABC}$-transporters. Phytomedicine. 2012;19:977-87. https://doi.org/10.1016/J.PHYMED.2012.05.010.

16. Shin J, Song M-H, Oh J-W, Keum Y-S, Saini RK. Pro-oxidant actions of carotenoids in triggering apoptosis of cancer cells: a review of emerging evidence. Antioxidants. 2020;9:1-17. https://doi.org/10.3390/ANTIOX9060 532.

17. Sowmya PR-R, Arathi BP, Vijay K, Baskaran V, Lakshminarayana R. Astaxanthin from shrimp efficiently modulates oxidative stress and allied cell death progression in MCF-7 cells treated synergistically with $\beta$-carotene and lutein from greens. Food Chem Toxicol. 2017;106:58-69. https://doi. org/10.1016/J.FCT.2017.05.024.

18. Ganesan P, Noda K, Manabe Y, Ohkubo T, Tanaka Y, Maoka T, et al. Siphonaxanthin, a marine carotenoid from green algae, effectively induces apoptosis in human leukemia (HL-60) cells. Biochim Biophys Acta. 2011;1810:497-503. https://doi.org/10.1016/J.BBAGEN.2011.02.008.

19. Gloria NF, Soares N, Brand C, Oliveira FL, Borojevic R, Teodoro AJ. Lycopene and beta-carotene induce cell-cycle arrest and apoptosis in human breast cancer cell lines. Anticancer Res. 2014;34:1377-86.

20. Liu C-L, Chiu Y-T, Hu M-L. Fucoxanthin enhances HO-1 and NOO1 expression in murine hepatic BNL CL.2 cells through activation of the Nrf2/ARE system partially by its pro-oxidant activity. J Agric Food Chem. 2011;59:11344-51. https://doi.org/10.1021/JF2029785.

21. Kotake-Nara E, Terasaki M, Nagao A. Characterization of apoptosis induced by fucoxanthin in human promyelocytic leukemia cells. Biosci Biotechnol Biochem. 2005;69:224-7. https://doi.org/10.1271/BBB.69. 224.

22. Wu H-L, Fu X-Y, Cao W-Q, Xiang W-Z, Hou Y-J, Ma J-K, et al. Induction of apoptosis in human glioma cells by fucoxanthin via triggering of ROS-mediated oxidative damage and regulation of MAPKs and PI3KAKT pathways. J Agric Food Chem. 2019;67:2212-9. https://doi.org/10. 1021/ACS.JAFC.8B07126.

23. Eid SY, Althubiti MA, Abdallah ME, Wink M, El-Readi MZ. The carotenoid fucoxanthin can sensitize multidrug resistant cancer cells to doxorubicin via induction of apoptosis, inhibition of multidrug resistance proteins and metabolic enzymes. Phytomedicine. 2020. https://doi. org/10.1016/J.PHYMED.2020.153280. 
24. de Júnior RG, Bonnet A, Braconnier E, Groult $H$, Prunier $G$, Beaugeard $L$, et al. Bixin, an apocarotenoid isolated from Bixa orellana $L$., sensitizes human melanoma cells to dacarbazine-induced apoptosis through ROS-mediated cytotoxicity. Food Chem Toxicol. 2019;125:549-61. https://doi.org/10.1016/J.FCT.2019.02.013.

25. Chou T-C. Drug combination studies and their synergy quantification using the Chou-Talalay method. Cancer Res. 2010;70:440-6. https://doi. org/10.1158/0008-5472.CAN-09-1947.

26. Nurcahyanti AD, Wink M. Cytotoxic potentiation of vinblastine and paclitaxel by L-canavanine in human cervical cancer and hepatocellular carcinoma cells. Phytomedicine. 2015;22:1232-7. https://doi.org/10. 1016/j.phymed.2015.10.007.

27. Nurcahyanti AD, Wink M. L-Canavanine potentiates the cytotoxicity of doxorubicin and cisplatin in arginine deprived human cancer cells. PeerJ. 2016. https://doi.org/10.7717/PEERJ.1542.

28. Chou T-C. Theoretical basis, experimental design, and computerized simulation of synergism and antagonism in drug combination studies. Pharmacol Rev. 2006;58:621-81. https://doi.org/10.1124/PR.58.3.10.

29. Cole S, Bhardwaj G, Gerlach J, Mackie J, Grant C, Almquist K, et al. Overexpression of a transporter gene in a multidrug-resistant human lung cancer cell line. Science. 1992;258:1650-4. https://doi.org/10.1126/SCIEN CE.1360704.

30. Amiri-Kordestani L, Basseville A, Kurdziel K, Fojo AT, Bates SE. Targeting MDR in breast and lung cancer: discriminating its potential importance from the failure of drug resistance reversal studies. Drug Resist Updat. 2012;15:50-61. https://doi.org/10.1016/J.DRUP.2012.02.002.

31. Teng Y-N, Sheu M-J, Hsieh Y-W, Wang R-Y, Chiang Y-C, Hung C-C. $\beta$-carotene reverses multidrug resistant cancer cells by selectively modulating human P-glycoprotein function. Phytomedicine. 2016;23:316-23. https://doi.org/10.1016/J.PHYMED.2016.01.008.

32. Sznarkowska A, Kostecka A, Meller K, Bielawski KP. Inhibition of cancer antioxidant defense by natural compounds. Oncotarget. 2017;8:15996. https://doi.org/10.18632/ONCOTARGET.13723.

33. Asadi-Samani M, Farkhad NK, Mahmoudian-Sani MR, Shirzad H. Antioxidants as a double-edged sword in the treatment of cancer. Antioxidants. 2019. https://doi.org/10.5772//NTECHOPEN.85468.

\section{Publisher's Note}

Springer Nature remains neutral with regard to jurisdictional claims in published maps and institutional affiliations.

Ready to submit your research? Choose BMC and benefit from:

- fast, convenient online submission

- thorough peer review by experienced researchers in your field

- rapid publication on acceptance

- support for research data, including large and complex data types

- gold Open Access which fosters wider collaboration and increased citations

- maximum visibility for your research: over 100M website views per year

At BMC, research is always in progress.

Learn more biomedcentral.com/submissions 